\title{
First report of Diaporthe foeniculina causing fruit rot of lemon in Turkey
}

\author{
Nasibe Tekiner ${ }^{1}$ (D) $\cdot$ Elif Tozlu ${ }^{1}$ (D) $\cdot$ Vladimiro Guarnaccia $^{2}$ (D) \\ Received: 21 March 2019 / Accepted: 31 August 2019/Published online: 16 October 2019 \\ (C) Società Italiana di Patologia Vegetale (S.I.Pa.V.) 2019
}

Keywords Phomopsis · Citrus · Molecular identification · Pathogenicity

Diaporthe spp. are pathogens, endophytes or saprobes on ornamentals, forest trees and economically important crops, causing different symptoms such as dieback, canker, leaf-spot, blight, fruit rot or wilt (Marin-Felix et al. 2019). During November 2018, a post harvest fruit rot was observed on lemon fruit (Citrus limon) in Mersin Province, south Turkey, with an incidence of $10 \%$. Brown and rough decay were present on fruit. Fungal colonies were obtained from single-spore isolation on potato dextrose agar (PDA). Colonies appeared first white, turning creamy to brown, with black, globose conidiomata. Beta conidia were smooth, hyaline, filiform, base truncate, straight or curved, $16-25 \times 1-2 \mu \mathrm{m}$. Alpha and gamma conidia were not observed. To confirm the identity, the internal transcribed spacer (ITS) region of the rDNA, was amplified and sequenced. The representative isolate (ET 88, GenBank accession no MK656290) showed $100 \%$ similarity with Diaporthe foeniculina CBS 111553 (NR145303).

Pathogenicity tests were performed on healthy lemon fruit after washing under tap water and surface's sterilized with $70 \%$ ethanol. Fruit were inoculated at the center with a $5 \mathrm{~mm}$ plugs obtained from 5-day old mycelial culture of the strain ET 88 grown on PDA at $26^{\circ} \mathrm{C}$ for 7 days. Control fruit were inoculated with PDA plugs. The fruit were kept in plastic containers with wet filter paper and incubated at room temperature for 10 days. After 5 days, the symptoms appeared on inoculated lemons. Control fruit remained healthy. The fungus was re-isolated only from diseased fruit, fulfilling Koch's postulates. Diaporthe foeniculina has been detected in Europe, USA and New Zeland, causing various symptoms on Citrus spp. (Guarnaccia and Crous 2017). To our knowledge, this is the first report of $D$. foeniculina causing lemon fruit rot in Turkey.

\section{References}

Guarnaccia V, Crous PW (2017) Emerging citrus diseases in Europe caused by species of Diaporthe. IMA Fungus 8:317-334

Marin-Felix Y, Hernández-Restrepo M, Wingfield MJ, Akulov A, Carnegie AJ, Cheewangkoon R, Gramaje D, Groenewald JZ, Guarnaccia V, Halleen F, Lombard L, Luangsaard J, Marincowitz S, Moslemi A, Mostert L, Quaedvlieg W, Schumacher RK, Spies CFJ, Thangavel R, Taylor PWJ, Wilson AM, Wingfield BD, Wood AR, Crous PW (2019) Genera of phytopathogenic fungi: GOPHY2. Studies in Mycology 92:47-133

Publisher's note Springer Nature remains neutral with regard to jurisdictional claims in published maps and institutional affiliations.

Elif Tozlu

elifalpertozlu@atauni.edu.tr

1 Department of Plant Protection, Faculty of Agriculture, Atatürk University, 25240 Erzurum, Turkey

2 DiSAFA, University of Torino, Largo Paolo Braccini, 2, 10095 Grugliasco, TO, Italy 